\title{
A Longitudinal Analysis of Job Satisfaction During a Recession in the Netherlands
}

\author{
Patrick Pilipiec $^{1}$ (D) $\cdot$ Wim Groot ${ }^{1,2} \cdot$ Milena Pavlova $^{2}$
}

Accepted: 22 November 2019 / Published online: 27 November 2019

(c) The Author(s) 2019

\begin{abstract}
Between 2008 and 2013, the Netherlands was confronted by a severe recession. This recession may have affected the job satisfaction of workers. Currently, little is known about how job satisfaction changes during a recession. To investigate the effect of the 2008-2013 recession on job satisfaction in the Netherlands, and to assess how job satisfaction changed over time. Longitudinal data from six waves of a national panel in the Netherlands are used to investigate the effects. These data capture the periods before, during and after the recession. A Blinder-Oaxaca decomposition technique is used to decompose the ordinal outcome variable job satisfaction. Subsequent waves are compared, which results in five comparison groups. Workers who participated in subsequent waves are matched to assess their job satisfaction over time. Cross-sectional associations are analyzed using the entire unmatched dataset. Workers became more satisfied with their job during the recession. After the recession ended, average job satisfaction decreased again. Both unmatched and matched analyses indicated only changes in job level affecting job satisfaction. The coefficient of education had a small effect cross-sectionally. The level of education and industry had a small effect longitudinally. However, these effects were not robust. Job satisfaction decreased before the recession commenced but increased during the recession. After the recession, job satisfaction decreased again. An increase in job satisfaction during the recession may be explained by a change in the composition of workers with respect to job level, instead of by the effect of predictors.
\end{abstract}

Keywords Blinder-Oaxaca decomposition · Decomposition analysis · Job satisfaction · Labor market outcome $\cdot$ Recession $\cdot$ The Netherlands

Patrick Pilipiec

patrick.pilipiec@maastrichtuniversity.nl

Wim Groot

w.groot@maastrichtuniversity.nl

Milena Pavlova

m.pavlova@maastrichtuniversity.nl

1 School of Business and Economics, Maastricht University, Tongersestraat 53, 6211 LM Maastricht, The Netherlands

2 Department of Health Services and Research, CAPHRI, Maastricht University Medical Center, Faculty of Health, Medicine and Life Sciences, Maastricht University, Duboisdomein 30, 6229 GT Maastricht, The Netherlands 


\section{Introduction}

The 2007 recession that started in the United States quickly engulfed many of the world's largest economies (Axelrad et al. 2017; Clench-Aas and Holte 2017; The Financial Crisis Inquiry Commission 2011). In Europe, many countries were confronted by a severe economic downturn in 2008, and a second recession in 2010 (Clench-Aas and Holte 2017; Karanikolos et al. 2013). Also, the Netherlands was in a recession between 2008 until the second quarter of 2013 (Boelhouwer 2017).

A recession is commonly defined as "two consecutive quarters of receding real GDP" (Leamer 2008, p. 3). In most countries of the European Union, the Gross Domestic Product (GDP) declined by on average $4.3 \%$ in 2009 (Arpaia and Curci 2010; Karanikolos et al. 2013). However, at the country-level, the decline ranged from $17.7 \%$ in Latvia to $1.9 \%$ in Cyprus (Karanikolos et al. 2013). Poland was the only EU member state that did not experience a decline in GDP (Karanikolos et al. 2013). Kickert (2012) concluded that, at that time, this recession was one of the largest challenges that Western countries were faced with.

In the Netherlands, the recession severely impacted the housing market between 2008 and 2013, where the annual number of transactions dropped from 225,000 to 100,000 properties, and where the nominal price of houses declined by $21 \%$ (Boelhouwer 2017). Furthermore, unemployment increased from $3.7 \%$ in 2008 to $7.3 \%$ in 2013, and pension benefits were lowered (Centraal Bureau voor de Statistiek 2019a; Clench-Aas and Holte 2017).

Recessions can have a negative effect in many areas of life. For example, there is an abundance of studies with evidence of a negative effect of a recession on health (Karanikolos et al. 2013). In the event of a recession, psychological well-being deteriorates due to an increased level of anxiety and depression (Gudmundsdottir 2013; Wilson and Walker 1993; World Health Organization 2009). Furthermore, there is evidence that experienced stress increases (World Health Organization 2009), mortality rates increase (Burgard et al. 2013), the incidence of lung cancer increases (Wilson and Walker 1993), and suicide rates among adults increase (Barr et al. 2012; Harper et al. 2015; Karanikolos et al. 2013; Laanani and Rey 2015; Miller et al. 2009; Reeves et al. 2015; Stuckler et al. 2009; World Health Organization 2009).

A recession also severely impacts organizations (Clench-Aas and Holte 2017). Organizations are confronted with problems related to their viability (Chatzopoulou et al. 2015), as many organizations experience significant reductions in their sales and profits, losses in market share, the lay-off of workers, and bankruptcy (Piperkova Majovski 2014).

Considering the significance of the negative impact of recessions, the interest in understanding the role of a recession on job satisfaction and its contribution to the organizational viability is relevant and important (Chatzopoulou et al. 2015). In addition, understanding the effect of a recession on job satisfaction is essential to develop effective policies that help governments and organizations to anticipate or even prevent negative effects of future financial crises on job satisfaction (Cho and Newhouse 2011).

\subsection{Job Satisfaction}

Job satisfaction is an attitude that was defined by Spector as "how people feel about their jobs and different aspects of their jobs. It is the extent to which people like (satisfaction) or dislike (dissatisfaction) their jobs" (Spector 1997, p. 2). Job satisfaction is therefore described as the "global feeling about the job or a related constellation of attitudes about various aspects or facets of the job" (Spector 1997, p. 2). Other studies (cf. Alegre et al. 
2016; Cheung and Wu 2013; Davies et al. 2017; Roelen et al. 2008) argue that job satisfaction results from the overall subjective evaluation of emotions, experiences, and beliefs that are associated to one's job.

Many different factors influence job satisfaction, which could be classified into four subgroups (Huysse-Gaytandjieva et al. 2013). First, socio-demographic characteristics like gender, age, health status, education, and marital status of workers. Second, personality attributes, which among others include factors like self-esteem, commitment, locus of control, and personality traits. Third, employment conditions, such as fulltime and part-time work, on-the-job training, and union membership influence job satisfaction. Fourth, workrelated contextual features like the local unemployment rate. The former two sub-groups involve personal characteristics of employees, while the latter two sub-groups are workrelated factors (Huysse-Gaytandjieva et al. 2013).

Job satisfaction is relevant because it is associated with a multitude of labor market outcomes. For example, studies have reported that job satisfaction is positively associated with productivity (Bousinakis and Halkos 2010; Patterson et al. 2004), greater employee intentions to stay (Meyer et al. 2002), stronger collective job performance (Whitman et al. 2010), decreased workplace turnover (Wright and Bonett 2007), and stronger organizational citizenship behaviors (Foote and Tang 2008).

It is found that organizations have a competitive advantage by employing more satisfied workers, and that increasing job satisfaction of employees can yield various benefits (Linz and Semykina 2012). For example, satisfied workers more often have a better job performance and are more likely to show organizational citizenship behaviors (Clark and Oswald 1996; Munyon et al. 2010). Therefore, employing satisfied workers is consistently associated with a viable company (Halkos and Bousinakis 2017). Considering the importance of job satisfaction and its positive effects on performance and productivity, maintaining high job satisfaction becomes even more important during a recession.

\subsection{Effect of a Recession on Job Satisfaction}

Evidence on the effect of a recession on job satisfaction is however limited and studies have reported inconsistent effects. For example, some authors provide evidence for a negative relationship (Cahill et al. 2015; Green et al. 2016; Halkos and Bousinakis 2017; Markovits et al. 2014), while there are also studies that find no relationship between a recession and job satisfaction (Gudmundsdottir 2013). In contrast, some studies reported a positive association between a recession and job satisfaction or well-being at work (Borra and GómezGarcía 2016; Sánchez-Sánchez and Namkee 2018). Perhaps these inconsistent findings can be explained by other characteristics than the state of the economy.

Aside from a direct impact of a recession on job satisfaction, the association between the two may be driven by the selection of workers, which may occur during a recession. Less satisfied workers may be more likely to become redundant during a recession. Industries where job satisfaction is lower, may be more affected by a recession leading to changes in the average job satisfaction during a recession. A decomposition of the change in job satisfaction in a part caused by changes in endowments or characteristics of workers, and another part caused by the change in the impact of these characteristics, may shed more light into this.

Cahill et al. (2015) concluded that in the advent of a strong economy, workers experienced a higher level of job satisfaction than if the economy was weaker. Another study found that employment conditions were severely and negatively impacted during an economic crisis, which resulted in a negative job evaluation by workers (Markovits et al. 
2014). Markovits et al. (2014) found that extrinsic job satisfaction became lower among employees after the financial crisis had started in Greece in 2009, and reported that these changes in attitude were explained by an increased focus on preventing job loss and a lesser focus on job promotion. Halkos and Bousinakis (2017) also reported that a recession reduces job satisfaction. In addition, a British study reported that, while well-being at work was stable prior to the recession, it substantially deteriorated in the 6 years during the recession (Green et al. 2016). In addition, the authors also observed that job insecurity deteriorated during the recession (Green et al. 2016).

However, regarding general happiness, one Icelandic study reported that the effect of the economic crisis on happiness was limited (Gudmundsdottir 2013). In contrast, while controlling for perceived job stability, a Spanish study reported that unemployment of peers positively affected individual's job-related well-being of males and workers in the public sector (Borra and Gómez-García 2016). Another Spanish study compared overall job satisfaction right before (2006-2007) and during (2009-2010) the recession, and found that overall job satisfaction had slightly increased during the recession (Sánchez-Sánchez and Namkee 2018). The authors suggested that this slight increase may be explained by factors that compensate for a reduction in job satisfaction during the recession (Sánchez-Sánchez and Namkee 2018).

The literature also suggests that the evaluation of job satisfaction of workers may be negatively affected by deteriorated employment conditions and job instability, by having fewer options for job promotion, and by an increased required performance to maintain organizational productivity. Likewise, workers may evaluate job satisfaction more positively during a recession because, while peers become unemployed and options for job mobility decrease, these workers still keep their job that protects them from the unwanted consequences of unemployment.

A recession results in higher unemployment rates (Piperkova Majovski 2014). In combination with decreased opportunities for job mobility, the possibilities for voluntary employee turnover decrease (Hom and Kinicki 2001). If employment opportunities are high, dissatisfied workers could more easily seek another job (Piperkova Majovski 2014). Instead, in a recession with high unemployment and low opportunities for job mobility, retaining one's employment becomes more important because employees may have no opportunities elsewhere and therefore have to remain employed at their current employer. The continued employment could however result in counterproductive behaviors, and if dissatisfied workers stay at the firm, this may be harmful for the organization (HuysseGaytandjieva et al. 2013). For example, dissatisfied workers may not only have lower job performance themselves, but could also negatively impact the job performance of their colleagues (Piperkova Majovski 2014).

\subsection{Aim of the Study}

Although the outcomes of job dissatisfaction have been studied abundantly, research that investigates the effect of a recession on job satisfaction remains scarce (Piperkova Majovski 2014), and the published findings are contradictory. In addition, we are not aware of any study that has specifically addressed how the job satisfaction of employees changed during the 2008-2013 recession in the Netherlands.

This longitudinal study therefore aims to fill this knowledge gap by investigating how job satisfaction in the Netherlands changed by and during a recession, and which differences of the predictors between the groups explain the differences in job satisfaction. These analyses 
are performed both using cross-sectional data and longitudinal data by using the nature of the panel and matching of participants who participated in subsequent data waves.

\section{Methods}

Data from the Arbeidsaanbodpanel (AAP) from the Netherlands Institute for Social Research (Sociaal en Cultureel Planbureau (SCP) 2016) are used. This ongoing prospective open cohort panel was established in 1985 with the purpose to study the work situation of both employed and unemployed inhabitants, and to gauge the (potential) labor supply in the Netherlands (Van Echtelt et al. 2016). The data are collected with a 2-year interval among approximately 5000 participants. Participation in this panel is stimulated by giving a small financial reward (Sociaal en Cultureel Planbureau 2014; Vlasblom et al. 2015). New participants are preselected to maintain the desired sample size, and to maintain the external validity for the entire population in the Netherlands (Vlasblom et al. 2015). Although the AAP includes a separate questionnaire for employed, unemployed, and students (Van Echtelt et al. 2016), in the present study, only the data collected with the questionnaire for the employed are used.

Because the recession in the Netherlands occurred from 2008 to 2013, data from six waves are used to perform the analyses before (2004: $N=4791,2006: N=5563)$, during (2008: $N=5139,2010: N=4872,2012: N=4837)$, and after (2014: $N=4948)$ this recession. No data are yet available for the year 2016 or later. Each participant has a unique identifier that identifies the person across the datasets.

The variable "year" was generated to record the year of the related measurement (either 2004, 2006, 2008, 2010, 2012, or 2014). In the resulting tidy and stacked dataset, the structure and semantics of a dataset are linked, which facilitates improved data analysis (cf. Wickham 2014).

The Blinder-Oaxaca decomposition (cf. Blinder 1973; Oaxaca 1973) was used to investigate the part of the differential in the means of the outcome that can be explained by the differences in observed characteristics of the two groups (i.e. endowments) and a part that can be explained by the impact of the predictors (i.e. coefficients) on the outcome variable (Hlavac 2018; Jann 2008a).

\subsection{Independent Variables}

For each data wave, the dataset contains nine variables that were used to explain differences in job satisfaction.

Information about the gender (1: "male", 2: "female") and the age of participants on the 1 st of October for each wave were retrieved from the Dutch national population register. We controlled for the age of participants in the analyses because younger and older workers may have different expectations and preferences toward jobs, and thus they may differ in their job satisfaction due to, for example, differences in ambition, tendency toward taking risks, and accumulated experience.

Level of education was measured according to the standard education classification SOI (cf. Centraal Bureau voor de Statistiek 2018c) using the self-report item "What is the highest educational program that you completed with a diploma?". The item was coded on a scale from 2 to 6 (2: "primary", 3: "lower secondary", 4: "secondary vocational and upper secondary", 5: "higher vocational", 6: "university"). 
The contractual working hours were measured using the self-report item "How many hours do you work per week contractually?".

The status of the participant as civil servant (0: "not civil servant", 1: "civil servant") was identified using the self-report item "How are you currently employed?". The values "regular salaried worker", "director of a corporation", "independent with personnel", "independent without personnel", and "working in the organization of the partner or spouse" were coded as "not civil servant". The value "civil servant" was retained as "civil servant".

Contract type (1: "permanent", 2: “temporary") was gauged using the self-report item "What contract type do you have?". The value "permanent contract" was retained as "permanent". The values "temporary with outlook on permanent contract", "temporary contract", and "other" were coded as "temporary".

Job level was measured using the standardized job classification scheme SBC (cf. Centraal Bureau voor de Statistiek 2018a). The job level was coded on a scale from 1 to 5 (1: "elementary", 2: "lower", 3: "middle", 4: "higher", 5: "academic"). There was no collinearity between the variables of level and education and job level in any data wave.

The industry of the organization where the participant is employed was categorized (1: "agriculture", 2: "manufacturing", 3: "construction", 4: "trade, hospitality and catering, repair", 5: "transportation", 6: "business services", 7: "human health and social work", 8: "other services", 9: "public administration", 10: "education") according to the Dutch Standard Industrial Classification (SBI) (Centraal Bureau voor de Statistiek 2018b, 2019b).

The datasets contain a variable that registered the year in which a person first participated in the AAP. This variable was used to create the dummy variable for first-time participation in each data wave. The value was set to 1 if the year of first participation equaled the year of data wave, and 0 otherwise.

Reported answers such as "not applicable", "I do not want to say", and illogical values were recoded into missing values.

\subsection{Dependent Variable}

Job satisfaction was measured using the self-report item "How satisfied are you, everything taken together, with your job?". The ordinal item was rated on a scale from 1 to 4 (1: "very satisfied", 2: "satisfied", 3: "not satisfied", 4: "very dissatisfied").

\subsection{Analyses}

The analyses are performed using cross-sectional (non-matched) and longitudinal (matched) data. For both, five analyses were performed to decompose the difference in job satisfaction between two data waves. In each analysis, data from two consecutive measurements were used to explain this difference by a change in the composition of groups (i.e. endowments), and by the effect of various independent variables on job satisfaction (i.e. coefficients).

When we use cross-sectional data, all participants in the panel are included to maintain the external validity for the Dutch working population. Therefore, each wave of the AAP is expected to meet the desired external validity and can be compared to other data waves. Five groups are created, Group 1: 2004-2006, Group 2: 2006-2008, Group 3: 2008-2010, Group 4: 2010-2012, and Group 5: 2012-2014. Thus, each group presented a subsequent crosssectional pair of data waves. For each group, the Blinder-Oaxaca decomposition analysis is performed. A dummy variable is generated to record the two subsequent data waves. The 
values of the categorical variables level of education, job level, and industry of organization are recoded into dummy variables. For the predictors level of education, job level, and industry of organization, the values "primary", "elementary", and "agriculture" are defined as reference categories, respectively. An indicator of being a newly entered participant in the survey is included as well. The analyses are performed using the Oaxaca module in Stata (Jann 2008a, b). The analyses are performed to decompose the gap of job satisfaction in the groups, where one part may be explained by differences in the predictors of two data waves, and one part may be explained by differences in the distribution of characteristics that affect job satisfaction (Hlavac 2018; Jann 2008a). This process is repeated for each group.

The longitudinal effects are investigated using panel data. Participants in subsequent waves are matched and are only included in the analyses if they participated in both data waves. Five groups are generated for respondents who participated in each subsequent pair of the data waves (Group 1: 2004-2006, Group 2: 2006-2008, Group 3: 2008-2010, Group 4: 2010-2012, Group 5: 2012-2014). Furthermore, as discussed above, a dummy variable is generated to record the two subsequent data waves for each group, which is entered into the Blinder-Oaxaca decomposition analysis to group the analysis.

\section{Results}

\subsection{Descriptive Statistics}

The sample characteristics of the six data waves are presented in Table 1. There are five notable trends to observe over the period 2004-2014.

First, the level of education of workers increased over time. The share of participants belonging to the level "lower secondary" strongly declined from $23.1 \%$ in 2004 to $15.6 \%$ in 2014. Simultaneously, the share of participants belonging to the levels "higher vocational" and "university" increased from 26.4 and $11.4 \%$ in 2014 to 29.5 and $14.4 \%$ in 2014, respectively.

Second, the share of participants who were civil servants declined from $19.9 \%$ in 2004 to $14.7 \%$ in 2014 .

Third, the share of participants who were temporary workers increased strongly from $10.8 \%$ in 2004 to $16.5 \%$ in 2014.

Fourth, the average job level increased over time. The share of participants at both lower and middle job levels decreased from 20.2 and $39.8 \%$ in 2004 to 14.8 and $35.1 \%$ in 2014 , respectively. Simultaneously, job level increased over time, where 27.5 and $7.7 \%$ of the participants worked at a higher or academic level in 2004, these levels were 35.7 and $10.3 \%$ in 2014 , respectively.

Fifth, the share of very satisfied workers increased as time progressed. A decrease in the share of very satisfied workers was only observed in 2006 and 2014. Relatively few workers were dissatisfied or very dissatisfied with their job during this period.

\subsection{Cross-Sectional Changes in the Effect on Job Satisfaction}

Five analyses were performed to decompose job satisfaction over time using cross-sectional (unmatched) data of two subsequent data waves. As time progressed, the raw difference in the means in job satisfaction changed sign (see Table 2). Workers were less satisfied with 


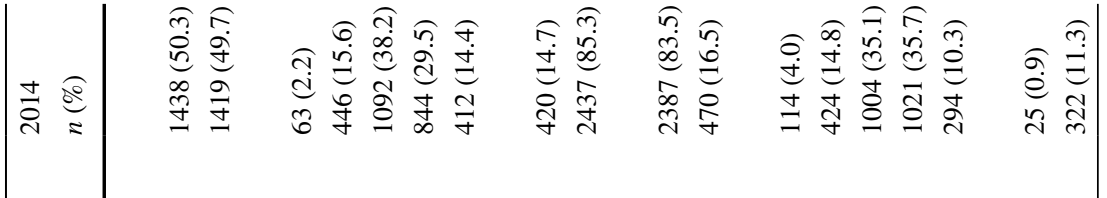

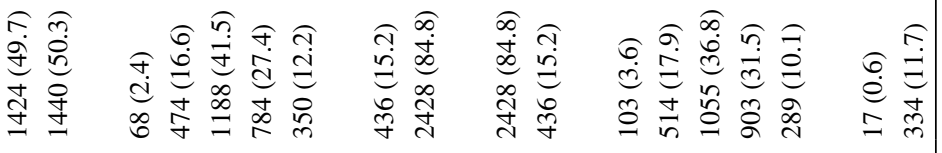

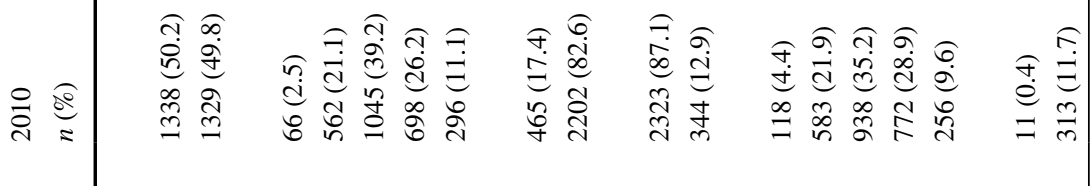

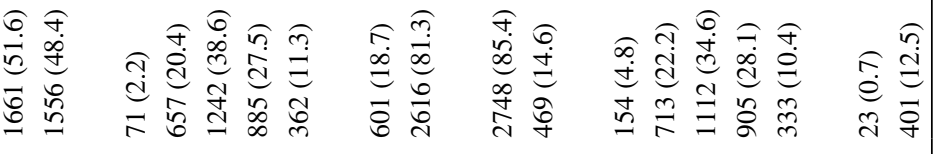

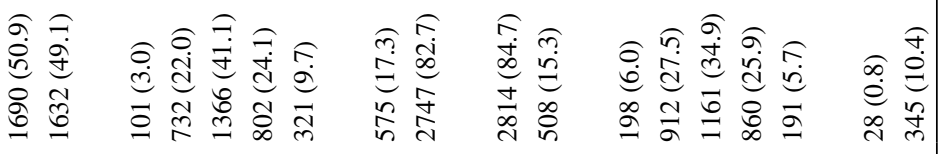

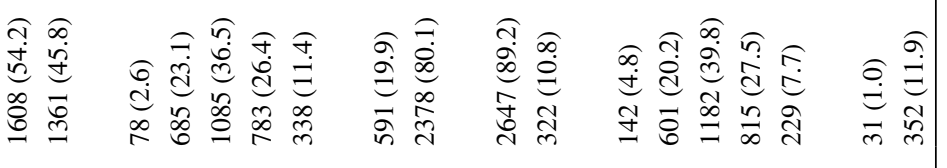

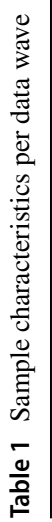

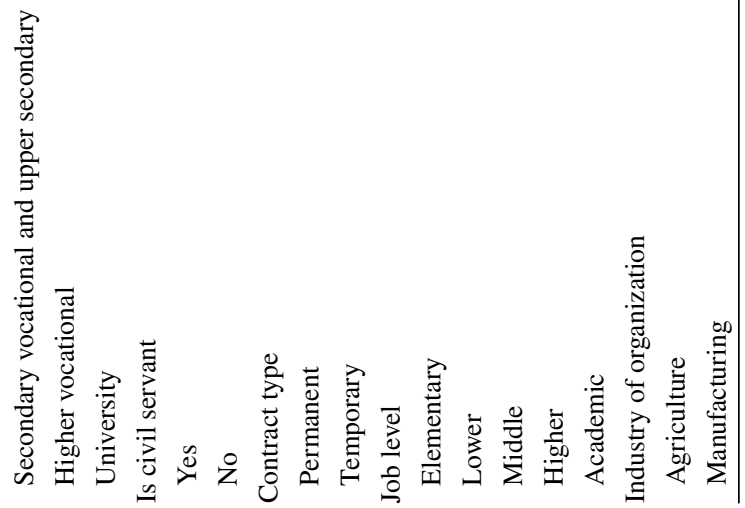




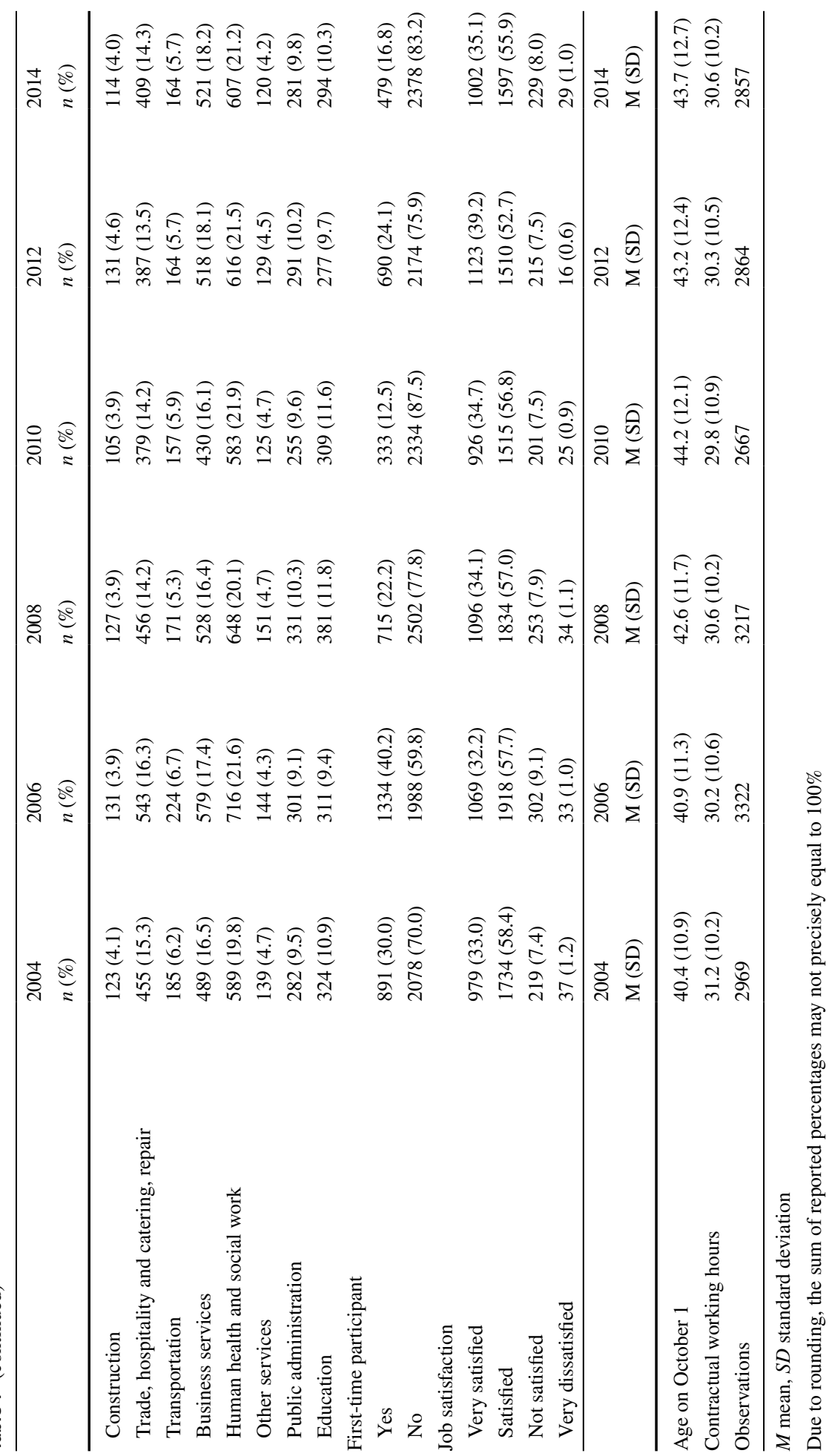


their job prior to the recession in the Netherlands (2004-2006). Once the recession commenced in 2008, job satisfaction increased, and continued to increase throughout the entire recession (2006-2012). Yet, once the economy recovered, job satisfaction decreased again (2012-2014). However, the intergroup difference was only statistically significant in Group 2 (2006-2008), Group 4 (2010-2012), and Group 5 (2012-2014).

The overall difference in the means of job satisfaction (see Table 2) cannot be fully explained by the changes in the composition of both groups (i.e. endowments). Instead, this difference is mainly explained by the impact of the independent variables on job satisfaction (i.e. coefficients). This impact was only statistically significant in Group 4 (2010-2012) and Group 5 (2012-2014).

Over time, there were only robust statistically significant changes in the composition of groups with respect to job level (see Table 3). In the group prior to the recession (2004-2006), there were fewer people who worked at middle or academic job levels, but more workers with lower jobs. In the waves during the recession (2006-2008), the share of workers with a higher or academic job level increased, while there were fewer people who worked in lower jobs. A similar change in composition occurred between 2010 and 2012 in the waves during the recession, where fewer workers worked in lower jobs and more in higher jobs. In the waves after the recession ended (2012-2014), this change in composition continued and the share of participants in higher jobs further increased, while fewer workers worked in lower jobs. In addition, while the composition changed slightly with respect to gender, age, contractual working hours, and contract type, these changes were however not robust over time.

Furthermore, the individual predictors did not have a robust impact on the differential of job satisfaction over time. The level of education did only have a significant effect on the differential in Group 3 and 5. Although other significant effects were observed, these results were limited to some variables (e.g., age, contractual working hours, contract type,

Table 2 Summary of cross-sectional (unmatched) decomposition of job satisfaction (1: "very satisfied", 2 : "satisfied", 3: "not satisfied", 4: "very dissatisfied")

\begin{tabular}{llllll}
\hline & Group 1 & Group 2 & Group 3 & Group 4 & Group 5 \\
& $2004-2006$ & $2006-2008$ & $2008-2010$ & $2010-2012$ & $2012-2014$ \\
\hline First wave & $1.769 * * *$ & $1.789 * * *$ & $1.759 * * *$ & $1.747 * * *$ & $1.694 * * *$ \\
& $(0.012)$ & $(0.011)$ & $(0.011)$ & $(0.012)$ & $(0.012)$ \\
Second wave & $1.789 * * *$ & $1.759 * * *$ & $1.747 * * *$ & $1.694 * * *$ & $1.750^{* * *}$ \\
Raw differential & $(0.011)$ & $(0.011)$ & $(0.012)$ & $(0.012)$ & $(0.012)$ \\
& -0.020 & $0.030^{*}$ & 0.012 & $0.053 * * *$ & $-0.056^{* * *}$ \\
Due to endowments & $(0.016)$ & $(0.016)$ & $(0.017)$ & $(0.017)$ & $(0.017)$ \\
\multirow{2}{*}{ Due to coefficients } & -0.003 & -0.003 & 0.000 & 0.000 & 0.002 \\
Due to interaction & $(0.004)$ & $(0.006)$ & $(0.005)$ & $(0.005)$ & $(0.004)$ \\
& -0.013 & 0.021 & 0.018 & $0.045 * *$ & $-0.056^{* * *}$ \\
Observations & $(0.017)$ & $(0.017)$ & $(0.017)$ & $(0.018)$ & $(0.017)$ \\
\hline
\end{tabular}

Standard errors in parentheses

*** $p<0.01$; ** $p<0.05$; * $p<0.1$ 


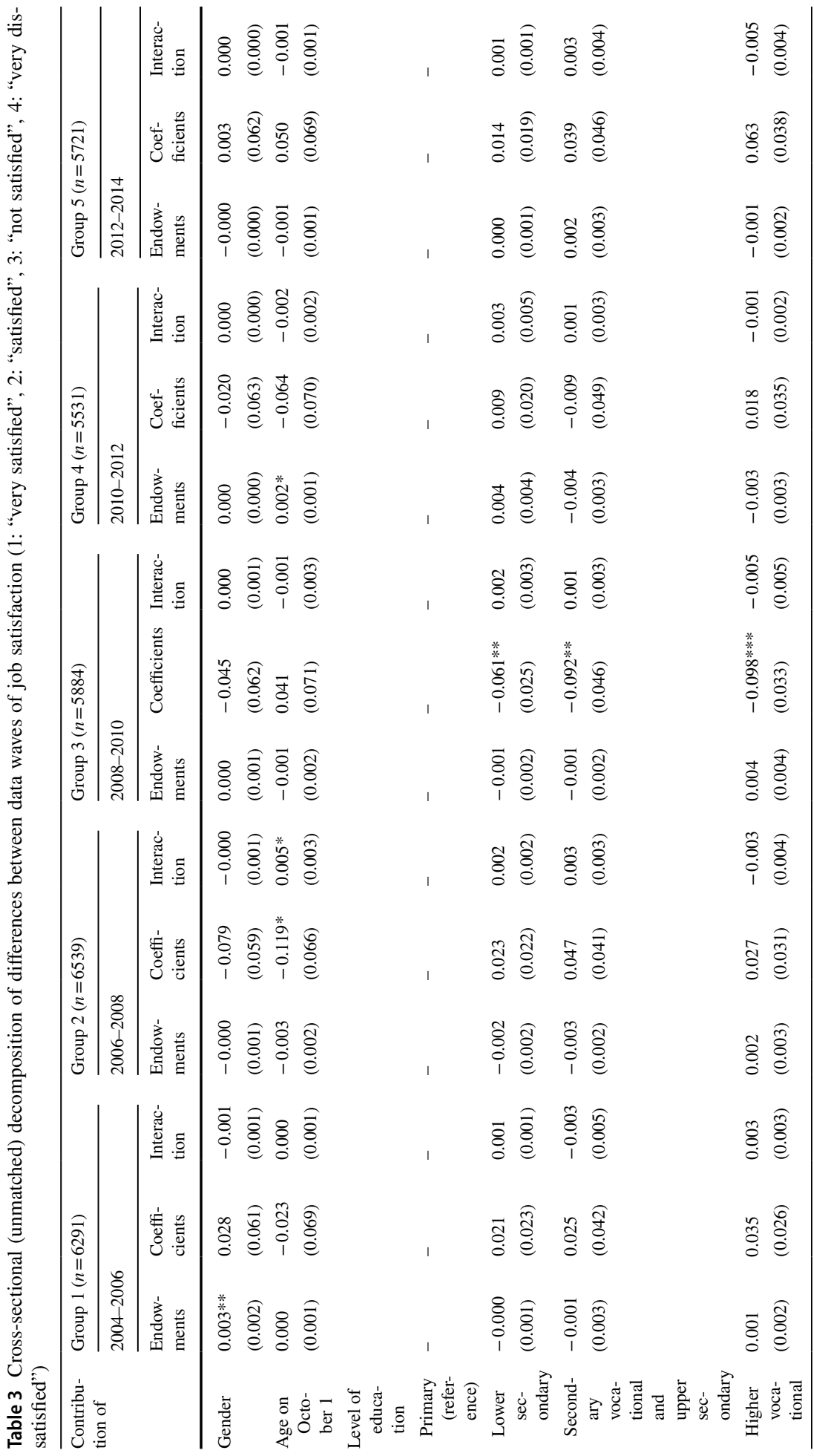




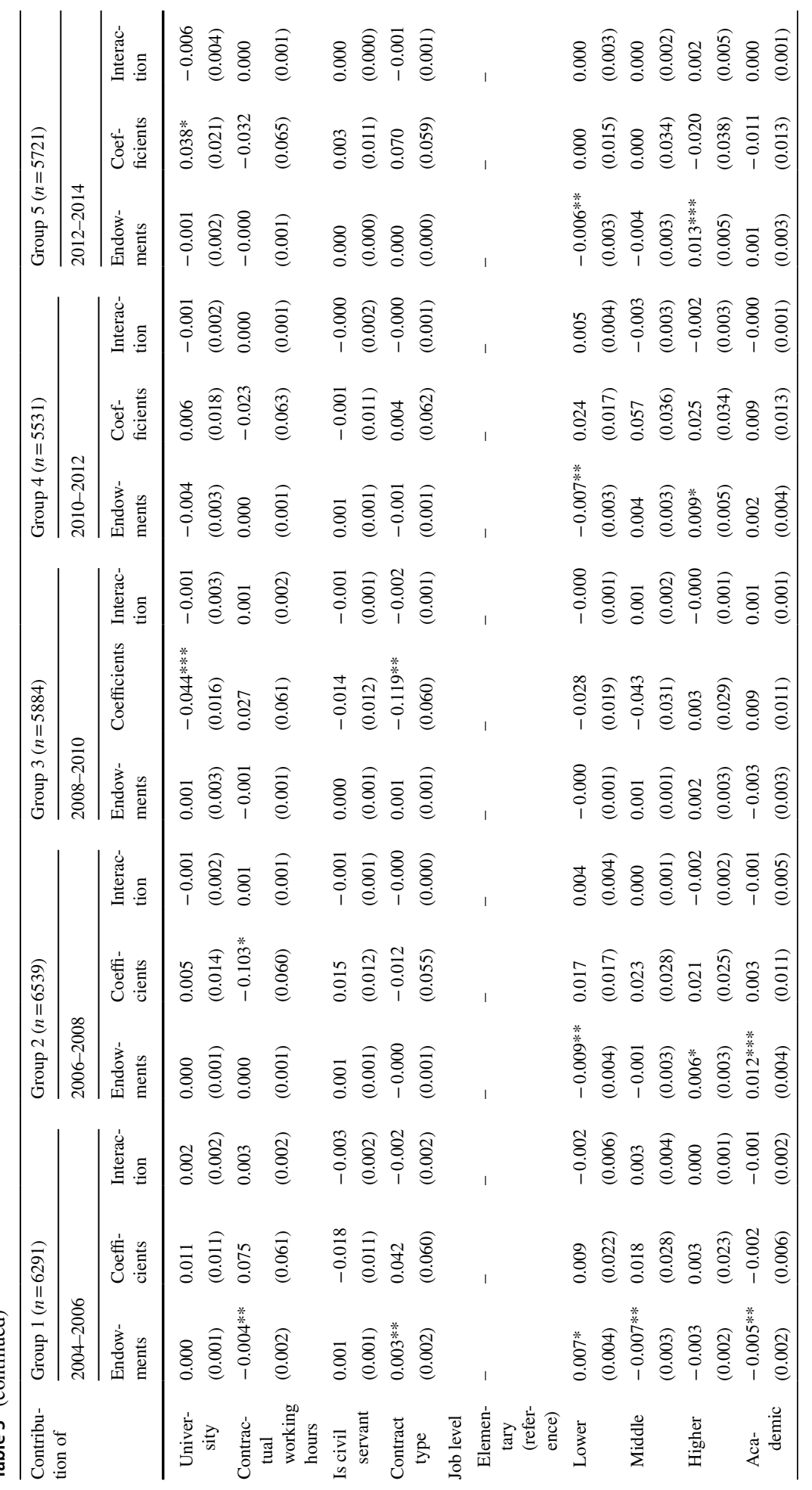




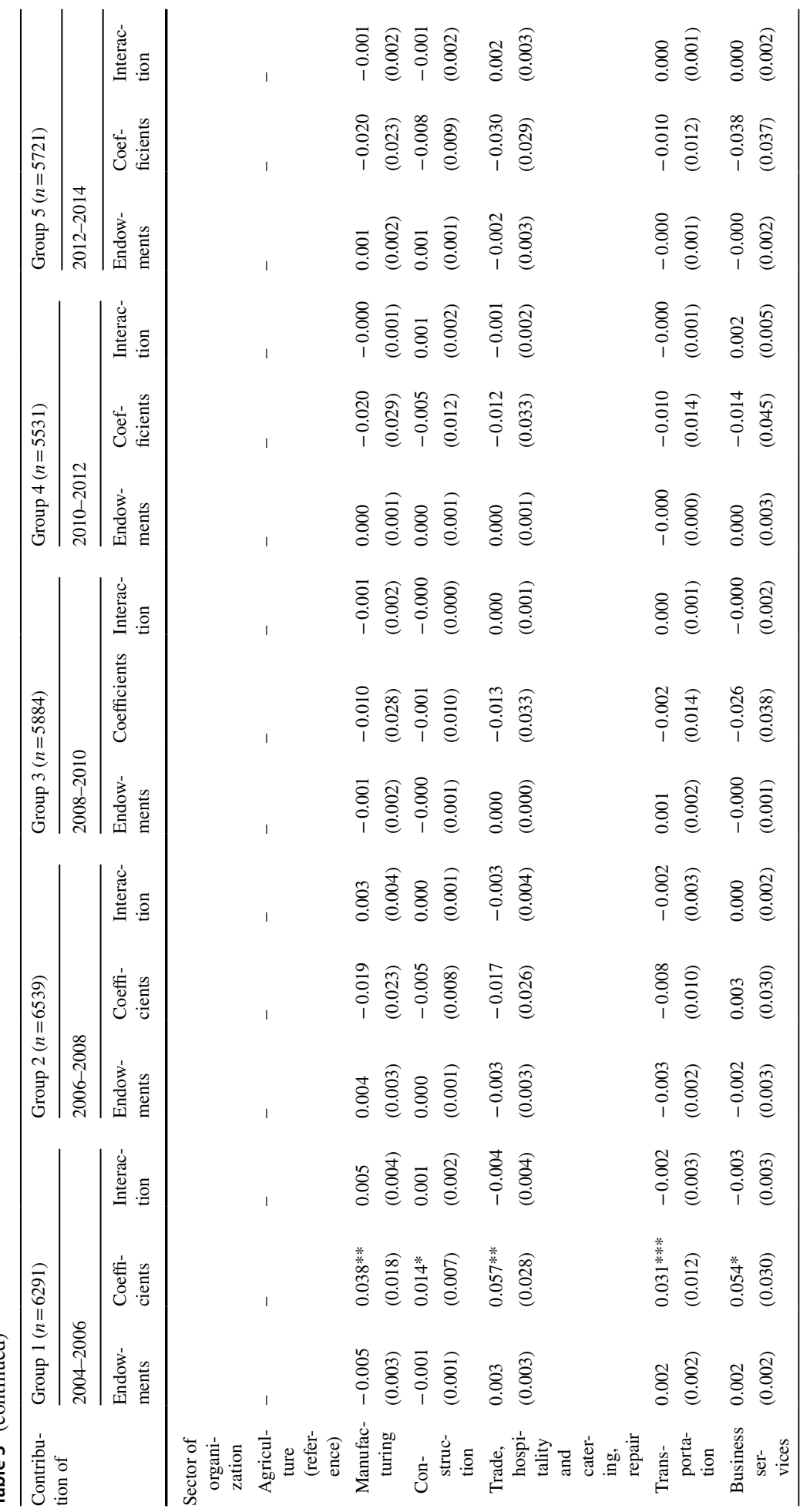




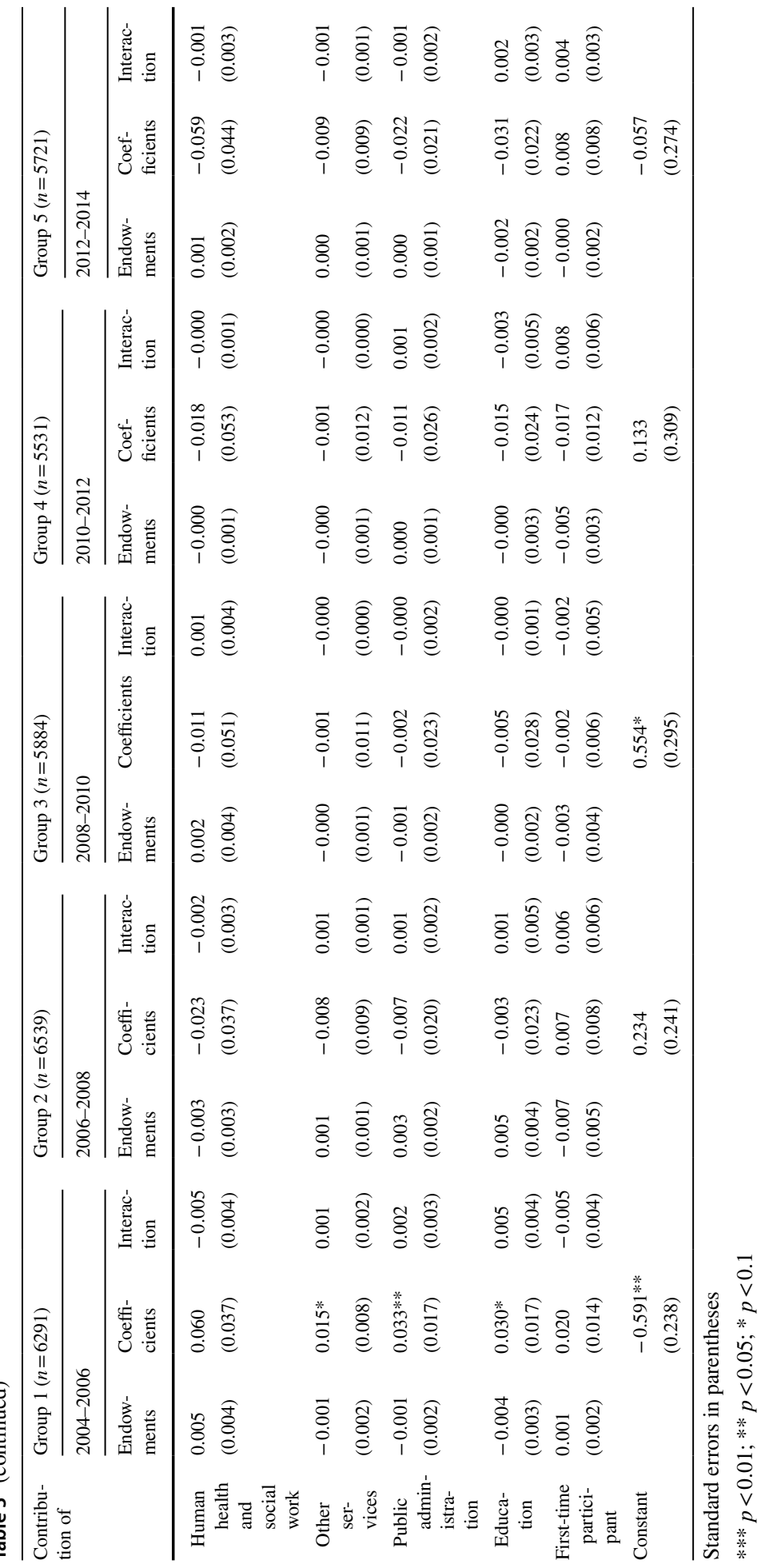


and sector of organization). See "Appendix 1" for the regression coefficients of the crosssectional (unmatched) decomposition.

\subsection{Longitudinal Changes in the Effect on Job Satisfaction}

Subsequently, five analyses were performed to decompose the difference in job satisfaction over time, using only matched workers who participated in both subsequent data waves.

Over time, there was an overall trend where the difference in the means of job satisfaction changed sign (see Table 4). Prior to the recession (2004-2006), job satisfaction decreased. Yet, once the recession commenced, the mean job satisfaction increased and continued to increase between 2006 and 2012. Nonetheless, after the recession ended (2012-2014), job satisfaction decreased again. However, the raw differential in job satisfaction was only statistically significant in Group 4 (2010-2012) and Group 5 (2012-2014).

The overall difference in the means of job satisfaction (see Table 4) can be explained by statistically significant changes in the composition in Group 2 (2006-2008). The endowment effects for the remaining groups were not statistically significant. In addition, this difference in job satisfaction could only be explained by a statistically significant effect of the independent variables in Group 4 and 5. The coefficients were not significant for the other groups.

Over time, there were only robust statistically significant changes in the composition of groups with respect to job level (see Table 5). Prior to the recession (2004-2006), the share of workers in middle and academic jobs decreased. However, once the recession commenced (2006-2008), the share of workers with an academic position increased, while there were fewer workers in lower jobs. Near the end of the recession (2010-2012), the share of workers in middle level jobs increased. But once the recession ended (2012-2014), the share of workers in higher-level jobs increased, while fewer persons worked in lower jobs.

Table 4 Summary of longitudinal (matched) decomposition of job satisfaction (1: "very satisfied", 2: "satisfied", 3: "not satisfied", 4: "very dissatisfied")

\begin{tabular}{llllll}
\hline & Group 1 & Group 2 & Group 3 & Group 4 & Group 5 \\
& $2004-2006$ & $2006-2008$ & $2008-2010$ & $2010-2012$ & $2012-2014$ \\
\hline First wave & $1.766^{* * *}$ & $1.784^{* * *}$ & $1.753^{* * *}$ & $1.739^{* * *}$ & $1.687^{* * * *}$ \\
& $(0.014)$ & $(0.013)$ & $(0.013)$ & $(0.014)$ & $(0.013)$ \\
Second wave & $1.785^{* * *}$ & $1.766^{* * *}$ & $1.749^{* * *}$ & $1.687^{* * *}$ & $1.753^{* * *}$ \\
& $(0.014)$ & $(0.013)$ & $(0.014)$ & $(0.014)$ & $(0.014)$ \\
Raw differential & -0.019 & 0.018 & 0.004 & $0.052^{* * *}$ & $-0.066^{* * *}$ \\
& $(0.020)$ & $(0.018)$ & $(0.019)$ & $(0.020)$ & $(0.019)$ \\
Due to endowments & 0.001 & $0.011^{* *}$ & 0.042 & 0.005 & 0.003 \\
& $(0.004)$ & $(0.004)$ & $(0.128)$ & $(0.004)$ & $(0.004)$ \\
Due to coefficients & -0.032 & 0.004 & 0.012 & $0.050^{* *}$ & $-0.066^{* * *}$ \\
Due to interaction & $(0.022)$ & $(0.021)$ & $(0.020)$ & $(0.020)$ & $(0.020)$ \\
Observations & 0.012 & 0.003 & -0.050 & -0.004 & -0.003 \\
\hline
\end{tabular}

Standard errors in parentheses

*** $p<0.01 ; * * p<0.05 ; * p<0.1$ 
Furthermore, no predictors had a robust statistically significant effect on the differential in job satisfaction. Two predictors had a statistically significant effect in only two groups. The effect of the level of education was negative in Group 3 (2008-2010) but positive in Group 5 (2012-2014). The effect of sector of organization was positive in Group 1 (2004-2006) but negative in Group 3 (2008-2010). The statistically significant effect of two other predictors was also not robust, where the independent variables being a civil servant and contract type both only had a negative effect in Group 3 (2008-2010). See "Appendix 2" for the regression coefficients of the longitudinal (matched) decomposition.

\section{Discussion}

This study investigated the effect of the 2008-2013 recession on job satisfaction in the Netherlands, and assessed how job satisfaction changed over time.

Similar to other studies (e.g., Cahill et al. 2015; Green et al. 2016; Halkos and Bousinakis 2017; Markovits et al. 2014; Sánchez-Sánchez and Namkee 2018), evidence was found that the recession had a positive effect on job satisfaction. Workers were consistently more satisfied with their job during the recession than before or after. Workers became more satisfied with their job once the recession commenced, then consistently had a higher job satisfaction during the recession, and finally became less satisfied with their job when the recession ended.

Furthermore, the sample characteristics demonstrate that the average level of education and the job level of workers have increased over time. Similarly, participants more often became precarious workers that were not a civil servant or that had a temporary contract. Furthermore, in all data waves, most workers were either satisfied or very satisfied with their job.

The decomposition analyses demonstrate that there was only a robust statistically significant change in the composition of groups with respect to job level, which contributes to the difference in job satisfaction. Overall, the job level prior to the recession decreased, but increased once the recession started. The increased job level probably also reflects the differences between workers in lower and higher-level jobs in becoming unemployed during the recession. For example, it suggests that workers in low-level jobs became redundant more often, while relatively higher-educated workers were more able to keep their job during and after the recession. This reflects the stronger and better position that workers at higher job levels have, but also the structural change in the labor market towards more highly skilled workers in higher job levels. It therefore indicates that workers in higher positions may enjoy better job security than workers in lower positions. In addition, the increase in level of education and job level may be explained by ongoing education by younger and unemployed persons. To prepare themselves for career opportunities once the recession ends, these persons may decide to continue education instead of actively seeking employment. Once the economy stabilizes, these persons are wellprepared to find employment on a higher job level. Consequently, if workers in higher job levels also have better job satisfaction, a decrease of workers in lower jobs and an increase of workers in higher jobs naturally increases the average job satisfaction.

Furthermore, there were no individual predictors that had a robust statistically significant impact on the change in job satisfaction. Instead, in the cross-sectional and longitudinal decomposition, there were indications that the level of education had an effect on the difference in job satisfaction. Similarly, in the longitudinal decomposition, there were indications that the level of education and the sector of organization had an effect on the difference in job satisfaction. However, these effects were not considered robust because these only appeared in only a few of the 


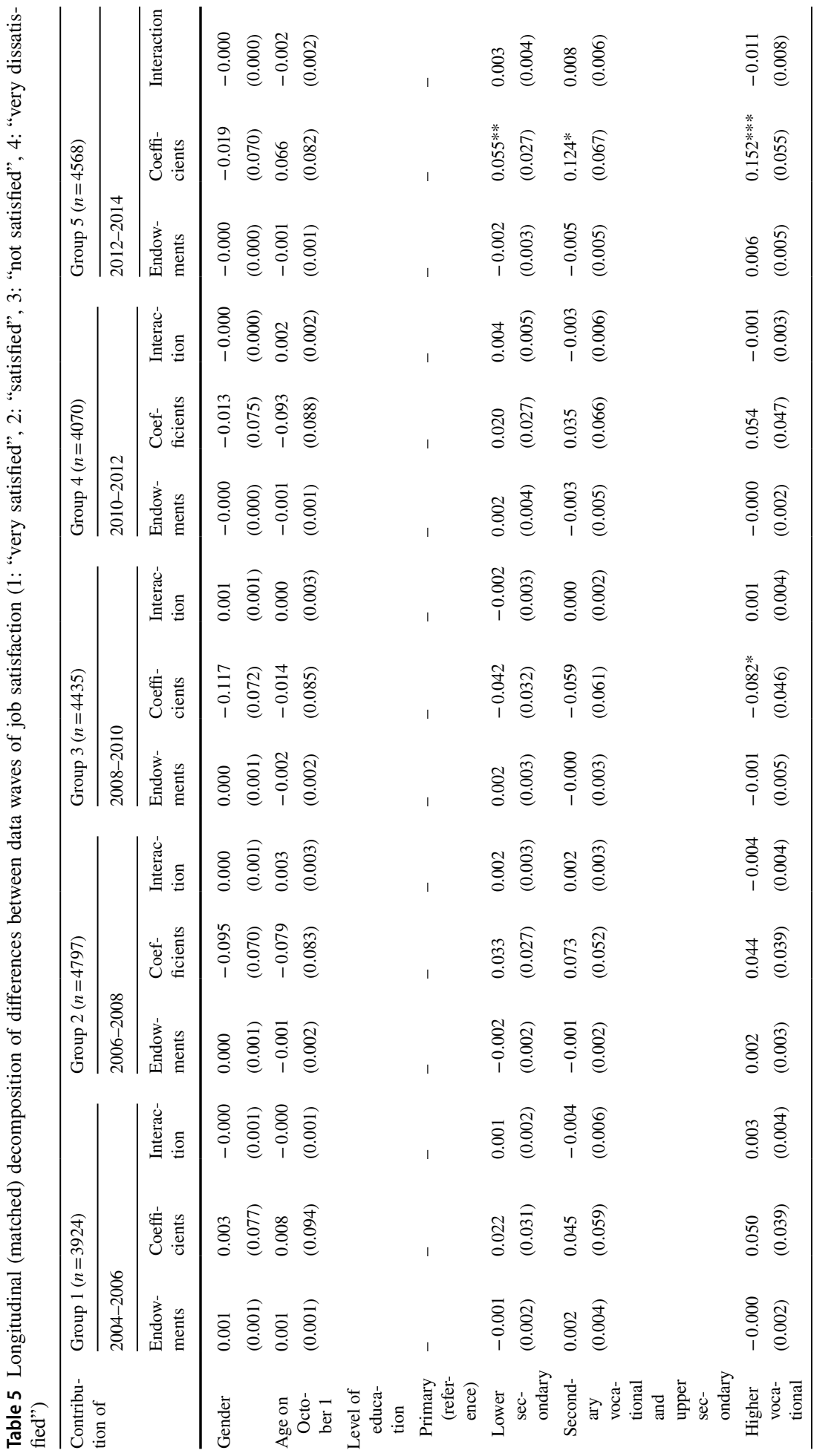




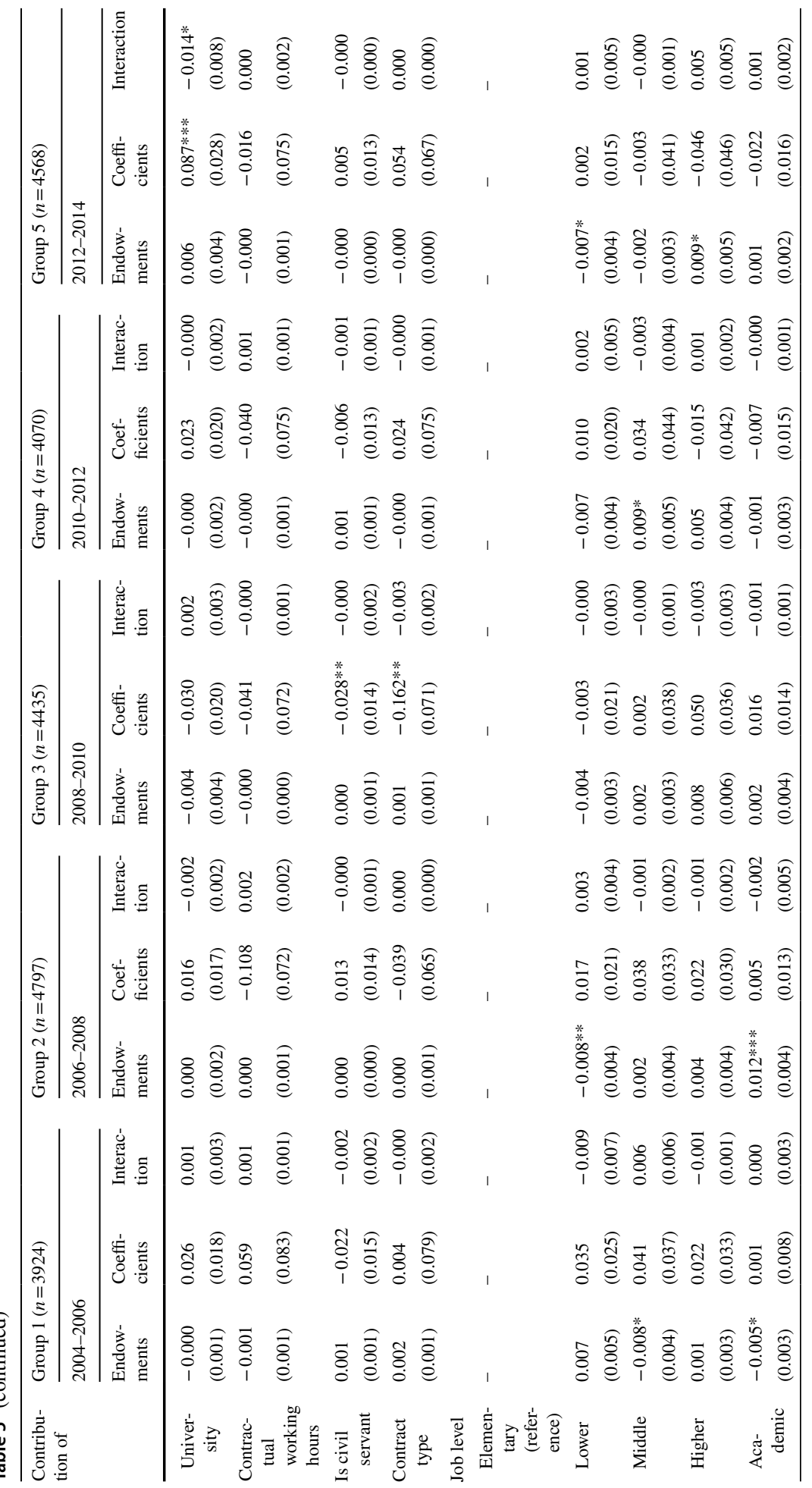




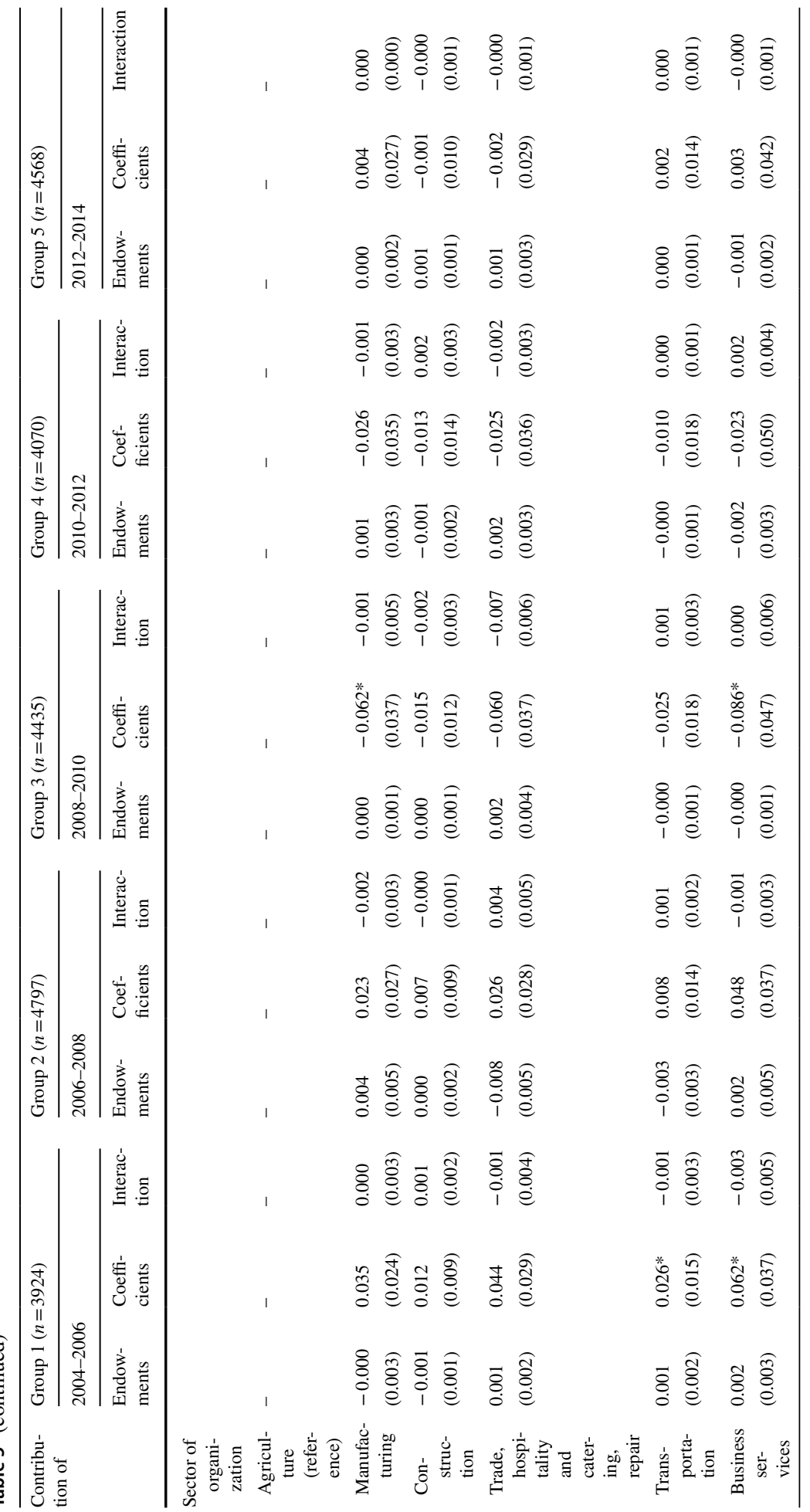




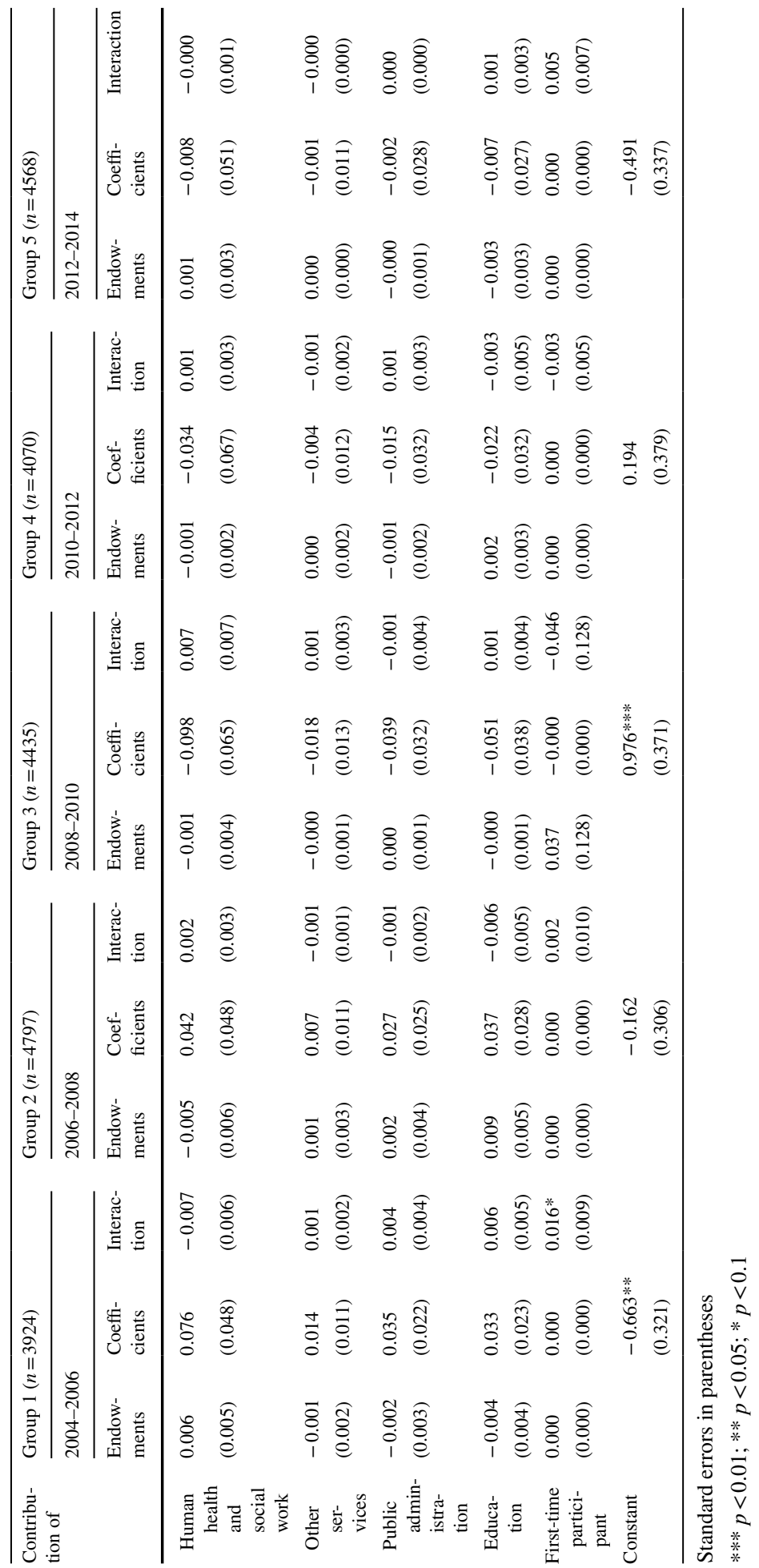


five groups. Nevertheless, this indicates that the level of education and sector of organization may be relevant in understanding changes in job satisfaction during a recession.

Perhaps the finding that job satisfaction increased during a recession can be better understood by considering the context of recessions. A recession has a negative effect on the sales, profits, and lost market share of organizations (Piperkova Majovski 2014). Consequently, during a recession, organizations are increasingly confronted with problems related to maintaining their viability (Chatzopoulou et al. 2015). One common strategy is cost-cutting by reducing the production capacity and by laying-off redundant workers, which results in increased unemployment rates (Axelrad et al. 2018; Clench-Aas and Holte 2017; Piperkova Majovski 2014). Therefore, the least satisfied workers may be laid off first while the most satisfied workers remain employed. Similarly, since alternative job opportunities during recessions decline and to avoid the hazardous state of unemployment, workers may also have no alternative than to remain employed by their current employer (Addison et al. 2014; Hom and Kinicki 2001; Johnson and Corcoran 2003). This selection may affect the composition of workers and increase the average job satisfaction of the remaining workers during the recession, if the least satisfied workers are dismissed first. However, once the recession ends and job mobility opportunities increase, these workers may find employment opportunities again (Piperkova Majovski 2014). Consequently, such post-recession selection may decrease the average level of job satisfaction.

In addition, the decomposition analyses also accounted for panel attrition that may result in potential differences between workers who participated for the first-time in the panel, and workers who participated already in an earlier wave. However, the findings confirm that there was no statistically significant effect of being a first-time participant on job satisfaction.

However, this does not exclude the possibility that there are other variables that can explain the difference between the groups which are not included in this model. For example, Huysse-Gaytandjieva and colleagues (Huysse-Gaytandjieva et al. 2013) have proposed the inclusion of personal characteristics and work-related factors when studying job satisfaction. Similarly, perhaps other characteristics of the economy and society may predict the relationship between a recession and job satisfaction. However, because of a lack of data on personality attributes, geographical information, and context features, the influence of these determinants could not be analyzed. Considering that the Netherlands is a relatively small country that has open borders with other countries, and that cross-border employment is common, it would be a challenge to investigate the effect of geographical information, especially because cross-border workers are subject to different legislations.

\subsection{Strengths and Limitations}

A strength of this study is that it investigated the effect of a recession on job satisfaction using cross-sectional and longitudinal data. These data were collected before (2004 and 2006), during (2008, 2010, and 2012), and after (2014) the 2008-2013 recession in the Netherlands, and facilitated the analysis of changes in job satisfaction over time. In addition to cross-sectional analysis using unmatched data, these changes in job satisfaction were also studied longitudinally using matched data, which facilitated a better understanding of how individual workers were impacted by this recession.

Furthermore, a problem with a panel is participant attrition. To account for potential attrition bias, we also investigated the potential existence of differences between first-time participants and those who had participated in the panel before, in explaining the difference in job satisfaction. However, we found no evidence of attrition bias.

This study has some noteworthy limitations. As discussed, many determinants of job satisfaction exist. Because of a lack of data, the influence of some of these determinants 
could not be analyzed. Specifically, the two most important determinants that could explain the results, but that were not included because of a lack of data, are personality characteristics and contextual factors. An important contextual factor that could be investigated is regional unemployment, but this information was not available in the dataset. Therefore, we recognize that other characteristics may have played a role in the relationship between recessions and job satisfaction, such as characteristics of the economy and society.

Another limitation involves the measurement of the level of education. We only observed job satisfaction for those who are in paid employment. Consequently, those who are in fulltime education but had a part-time job alongside, were not included in the analyses. Furthermore, if a participant is in school and does not work, we are unable to observe job satisfaction, since job satisfaction is only observed for persons who actually work. While we acknowledge that there exists a grey area for participants who are enrolled in a degree instead of being graduated, the datasets did not include this information.

Third, this study did not consider the geographical location of employment. Even within countries, the labor market may differ between cities or regions. However, our dataset does not include the necessary geographical information, nor was it possible to impute this information. Our dataset did also not account for cross-border workers, which is fairly common in the Netherlands.

\section{Conclusion}

To conclude, the recession had a positive effect on job satisfaction in the Netherlands, and job satisfaction increased during this recession. However, when the recession ended, job satisfaction decreased again. It may be possible that, in times of organizational survival, the least motivated workers became redundant first, such that mostly motivated and satisfied workers remained employed. In line with this assumption, evidence was found that the composition of workers changed with respect to job level, where job level increased during the recession, which may explain the change in job satisfaction. No individual predictors had a robust effect on the difference in job satisfaction, yet the level of education and sector of organization may need further investigation to better understand their effect on job satisfaction during a recession.

Author's contribution PP conducted this study. All authors contributed to the text of the manuscript and read and have approved the final article.

Funding This study was funded by the Department of Health Services Research at Maastricht University.

\section{Compliance with ethical standards}

Conflict of interest The authors declare that they have no competing interests.

Open Access This article is distributed under the terms of the Creative Commons Attribution 4.0 International License (http://creativecommons.org/licenses/by/4.0/), which permits unrestricted use, distribution, and reproduction in any medium, provided you give appropriate credit to the original author(s) and the source, provide a link to the Creative Commons license, and indicate if changes were made.

\section{Appendix 1}

See Table 6. 


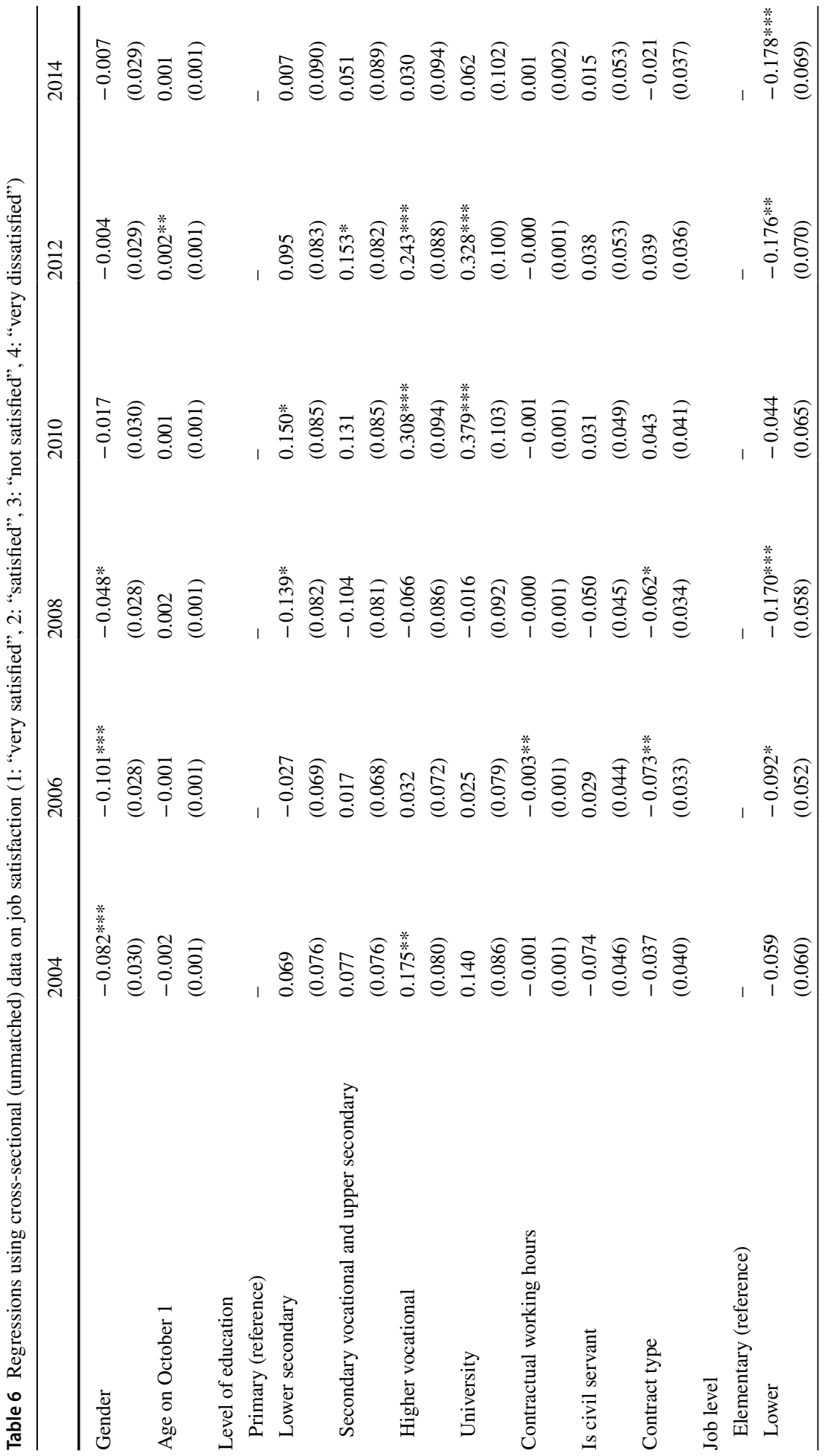




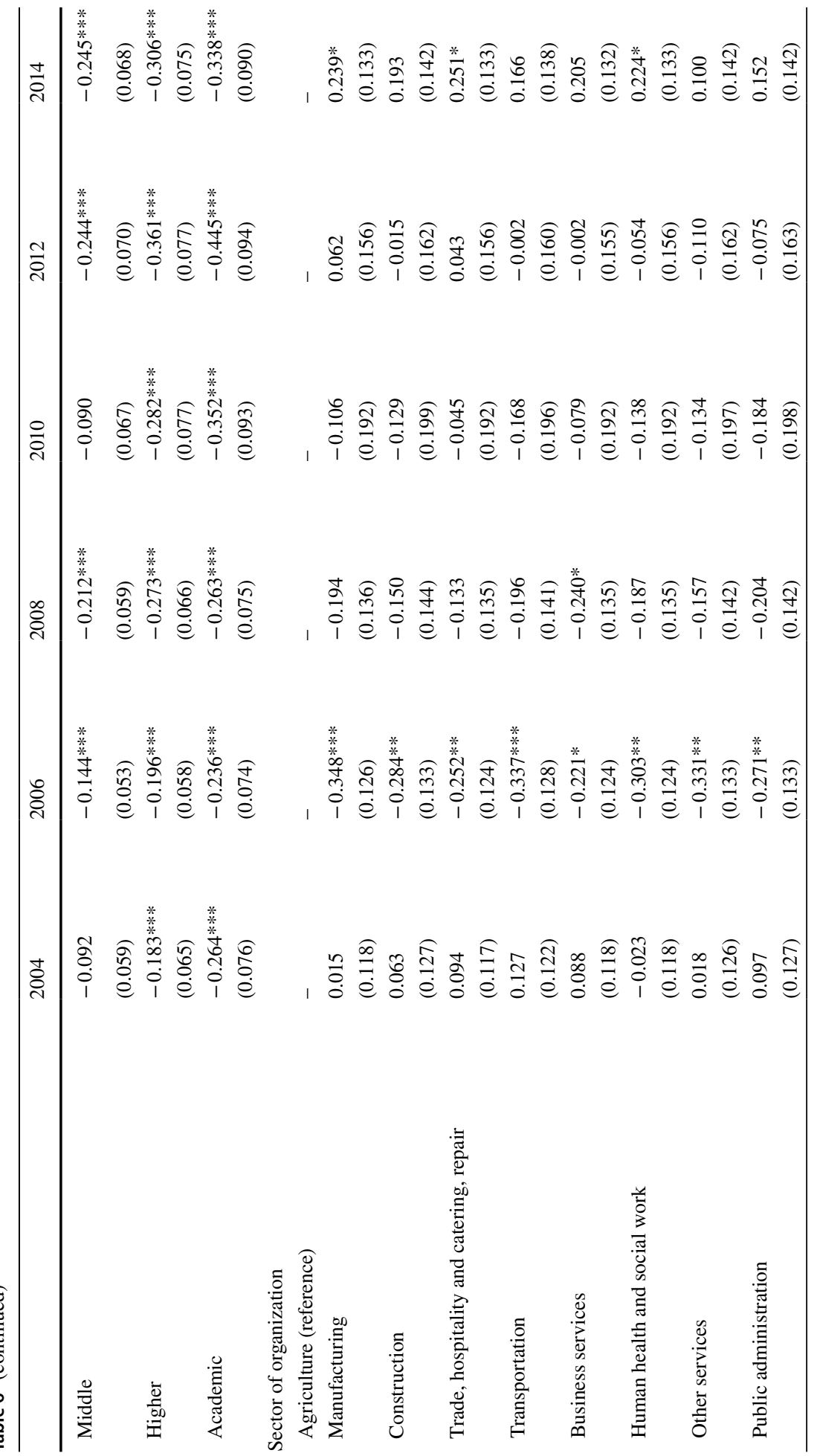




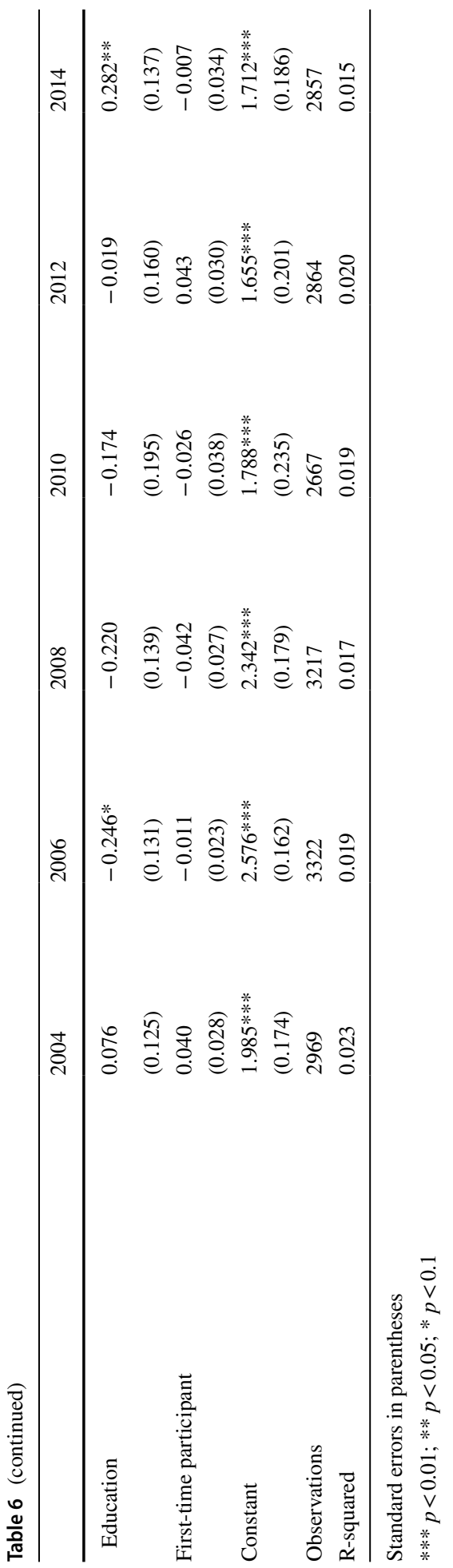




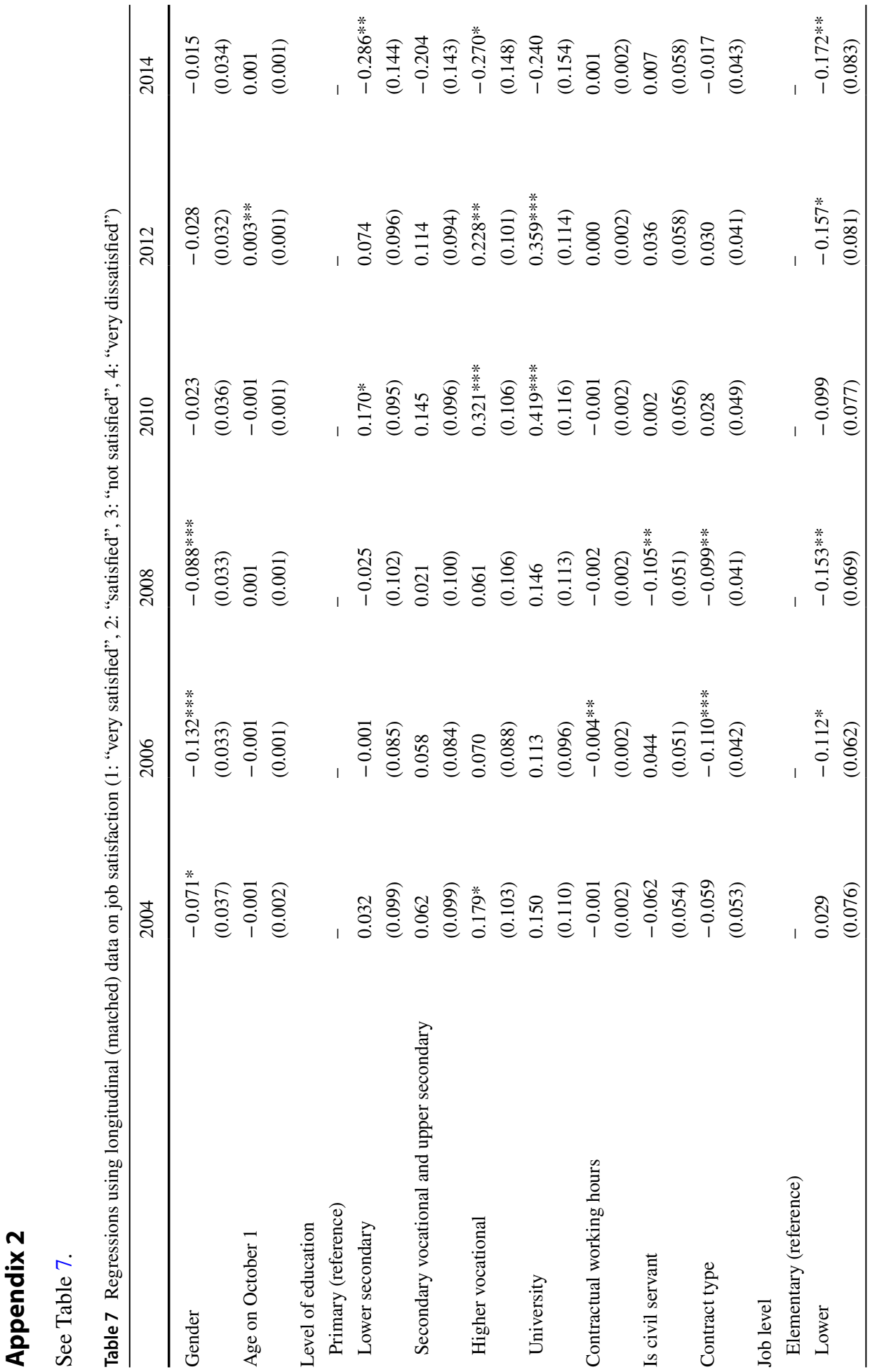




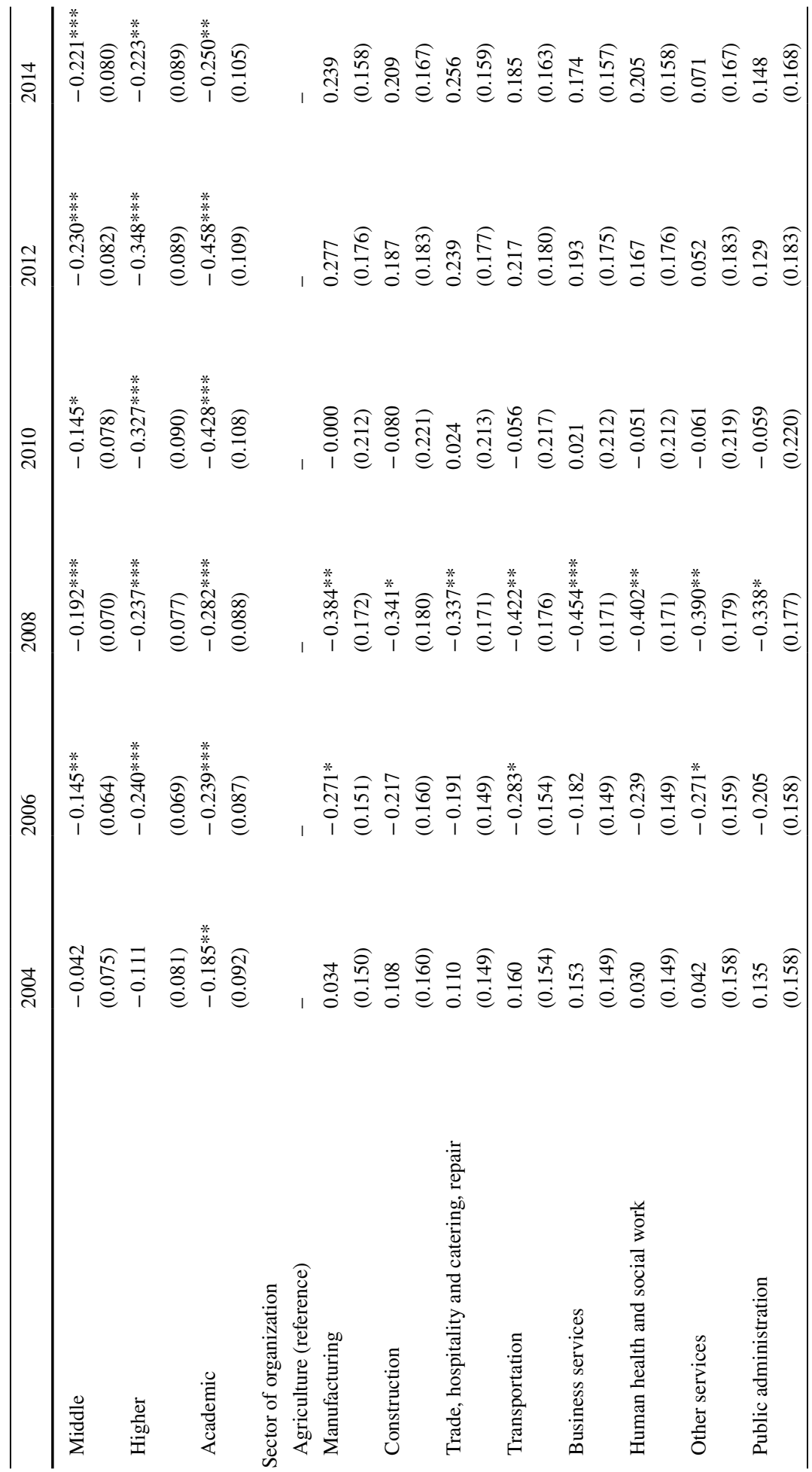




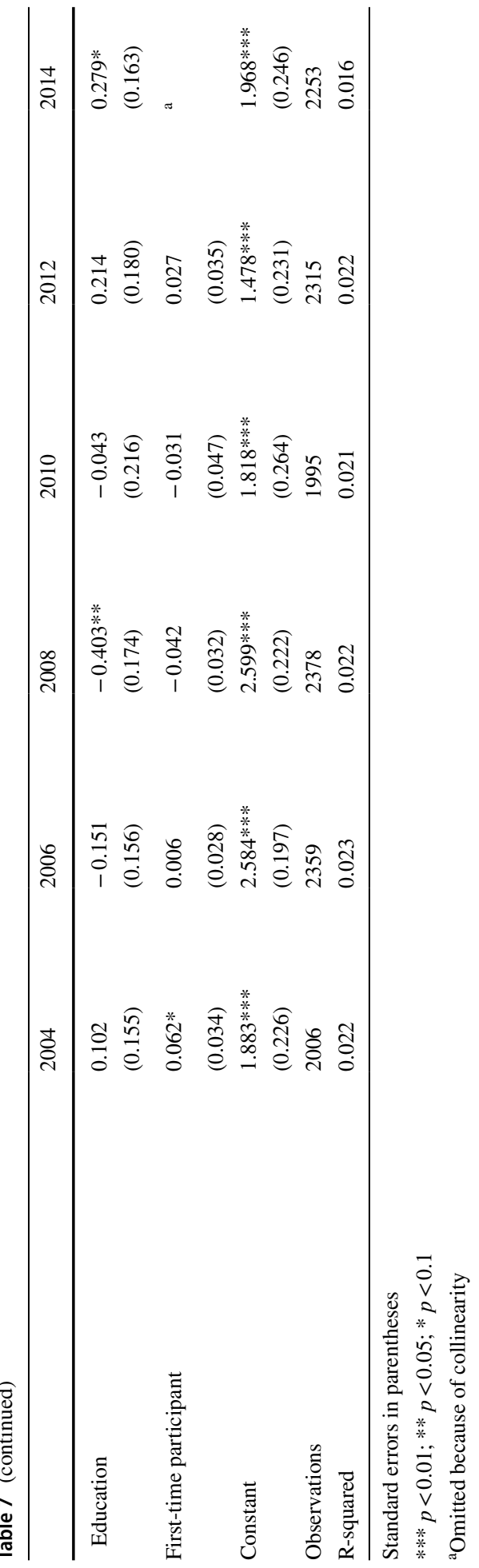




\section{References}

Addison, J. T., Ozturk, O. D., \& Wang, S. (2014). Job promotion in midcareer: Gender, recession, and "crowding". Monthy Labor Review, 1(1), 1-20.

Alegre, I., Mas-Machuca, M., \& Berbegal-Mirabent, J. (2016). Antecedents of employee job satisfaction: Do they matter? Journal of Business Research, 69(4), 1390-1395.

Arpaia, A., \& Curci, N. (2010). EU labour market behaviour during the Great Recession (Vol. 405). Brussels: European Commission.

Axelrad, H., Sabbath, E. L., \& Hawkins, S. S. (2017). The impact of the 2008 recession on the health of older workers: Data from 13 European countries. European Journal of Public Health, 27(4), 647-652.

Axelrad, H., Sabbath, E. L., \& Hawkins, S. S. (2018). The 2008-2009 Great Recession and employment outcomes among older workers. European Journal of Ageing, 15(1), 35-45.

Barr, B., Taylor-Robinson, D., Scott-Samuel, A., McKee, M., \& Stuckler, D. (2012). Suicides associated with the 2008-10 economic recession in England: Time trend analysis. BMJ, 345, e5142.

Blinder, A. S. (1973). Wage discrimination: Reduced form and structural estimates. The Journal of Human Resources, 8(4), 436-455.

Boelhouwer, P. (2017). The role of government and financial institutions during a housing market crisis: A case study of the Netherlands. International Journal of Housing Policy, 17(4), 591-602.

Borra, C., \& Gómez-García, F. (2016). Wellbeing at work and the Great Recession: The effect of other's unemployment. Journal of Happiness Studies, 17, 1939-1962.

Bousinakis, D., \& Halkos, G. (2010). The effect of stress and satisfaction on productivity. International Journal of Productivity and Performance Management, 59(5), 415-431.

Burgard, S. A., Ailshire, J. A., \& Kalousova, L. (2013). The Great Recession and health: People, populations, and disparities. The ANNALS of the American Academy of Political and Social Science, 650(1), 194-213.

Cahill, K. E., McNamara, T. K., Pitt-Catsouphes, M., \& Valcour, M. (2015). Linking shifts in the national economy with changes in job satisfaction, employee engagement and work-life balance. Journal of Behavioral and Experimental Economics, 56, 40-54.

Centraal Bureau voor de Statistiek. (2018a). Beroepenclassificatie (ISCO en SBC) [Job classification (ISCO and $S B C)$ ]. Retrieved from https://www.cbs.nl/nl-nl/onze-diensten/methoden/classificaties/onderwijsen-beroepen/beroepenclassificatie-isco-en-sbc-.

Centraal Bureau voor de Statistiek. (2018b). SBI 2008-Standaard Bedrijfsindeling 2008 [SBI 2008Standardized Corporate Classification 2008]. Retrieved from https://www.cbs.nl/nl-nl/onze-diens ten/methoden/classificaties/activiteiten/sbi-2008-standaard-bedrijfsindeling-2008.

Centraal Bureau voor de Statistiek. (2018c). Standaard Onderwijsindeling (SOI). Retrieved from https ://www.cbs.nl/nl-nl/onze-diensten/methoden/classificaties/onderwijs-en-beroepen/standaard-onder wijsindeling-soi-.

Centraal Bureau voor de Statistiek. (2019a). Arbeidsdeelname en werkloosheid per maand [Work participation and unemployment by month]. Retrieved from https://opendata.cbs.nl/statline/\#/CBS/nl/ dataset/80590ned/table?dl=16CC3.

Centraal Bureau voor de Statistiek. (2019b). Standard industrial classifications (Dutch SBI 2008, NACE and ISIC). Retrieved from https://www.cbs.nl/en-gb/our-services/methods/classifications/activiteit en/standard-industrial-classifications-dutch-sbi-2008-nace-and-isic-.

Chatzopoulou, M., Vlachvei, A., \& Monovasilis, T. (2015). Employee's motivation and satisfaction in light of economic recession: Evidence of Grevena prefecture-Greece. Procedia Economics and Finance, 24, 136-145.

Cheung, F., \& Wu, A. M. S. (2013). Older workers' successful aging and intention to stay. Journal of Managerial Psychology, 28(6), 645-660.

Cho, Y., \& Newhouse, D. (2011). How did the Great Recession affect different types of workers? Evidence from 17 middle-income countries. Policy Research working paper, no. WPS 5636. World Bank.

Clark, A. E., \& Oswald, A. J. (1996). Satisfaction and comparison income. Journal of Public Economics, 61(3), 359-381.

Clench-Aas, J., \& Holte, A. (2017). The financial crisis in Europe: Impact on satisfaction with life. Scandinavian Journal of Public Health, 45(18_suppl), 30-40.

Davies, E. M. M., Van der Heijden, B. I. J. M., \& Flynn, M. (2017). Job satisfaction, retirement attitude and intended retirement age: A conditional process analysis across workers' level of household income. Frontiers in Psychology, 8, 891. 
Foote, D. A., \& Tang, T. L. P. (2008). Job satisfaction and organizational citizenship behavior (OCB): Does team commitment make a difference in self-directed teams? Management Decision, 46(6), 933-947.

Green, F., Felstead, A., Gallie, D., \& Inanc, H. (2016). Job-related well-being through the Great Recession. Journal of Happiness Studies, 17, 389-411.

Gudmundsdottir, D. G. (2013). The impact of economic crisis on happiness. Social Indicators Research, $110(3), 1083-1101$.

Halkos, G., \& Bousinakis, D. (2017). The effect of stress and dissatisfaction on employees during crisis. Economic Analysis \& Policy, 55, 25-34.

Harper, S., Charters, T. J., Strumpf, E. C., Galea, S., \& Nandi, A. (2015). Economic downturns and suicide mortality in the USA, 1980-2010: Observational study. International Journal of Epidemiology, 44(3), 956-966.

Hlavac, M. (2018). oaxaca: Blinder-Oaxaca decomposition in R. Retrieved from https://cran.r-proje ct.org/web/packages/oaxaca/vignettes/oaxaca.pdf.

Hom, P. W., \& Kinicki, A. J. (2001). Toward a greater understanding of how dissatisfaction drives employee turnover. Academy of Management Journal, 44(5), 975-987.

Huysse-Gaytandjieva, A., Groot, W., \& Pavlova, M. (2013). A new perspective on job lock. Social Indicators Research, 112(3), 587-610.

Jann, B. (2008a). The Blinder-Oaxaca decomposition for linear regression models. The Stata Journal, $8(4), 453-479$.

Jann, B. (2008b). A Stata implementation of the Blinder-Oaxaca decomposition. The Stata Journal, 8(4), 453-479.

Johnson, R. C., \& Corcoran, M. E. (2003). The road to economic self-sufficiency: Job quality and job transition patterns after welfare reform. Journal of Policy Analysis and Management, 22(4), 615-639.

Karanikolos, M., Mladovsky, P., Cylus, J., Thomson, S., Basu, S., Stuckler, D., et al. (2013). Financial crisis, austerity, and health in Europe. The Lancet, 381(9874), 1323-1331.

Kickert, W. (2012). State responses to the fiscal crisis in Britain, Germany and the Netherlands. Public Management Review, 14(3), 299-309.

Laanani, M., \& Rey, G. (2015). Impact of unemployment rate and the economic crisis on suicide mortality in Western European countries (2000-2010). European Journal of Public Health, 25(suppl_3), 51-52.

Leamer, E. E. (2008). What's a recession, anyway? National Bureau of Economic Research Working Paper Series, No. 14221.

Linz, S. J., \& Semykina, A. (2012). What makes workers happy? Anticipated rewards and job satisfaction. Industrial Relations: A Journal of Economy and Society, 51(4), 811-844.

Markovits, Y., Boer, D., \& van Dick, R. (2014). Economic crisis and the employee: The effects of economic crisis on employee job satisfaction, commitment, and self-regulation. European Management Journal, 32(3), 413-422.

Meyer, J. P., Stanley, D. J., Herscovitch, L., \& Topolnytsky, L. (2002). Affective, continuance, and normative commitment to the organization: A meta-analysis of antecedents, correlates, and consequences. Journal of Vocational Behavior, 61(1), 20-52.

Miller, D. L., Page, M. E., Stevens, A. H., \& Filipski, M. (2009). Why are recessions good for your health? The American Economic Review, 99(2), 122-127.

Munyon, T. P., Hochwarter, W. A., Perrewé, P. L., \& Ferris, G. R. (2010). Optimism and the nonlinear citizenship behavior-job satisfaction relationship in three studies. Journal of Management, 36(6), $1505-1528$.

Oaxaca, R. (1973). Male-female wage differentials in urban labor markets. International Economic Review, 14(3), 693-709.

Patterson, M., Warr, P., \& West, M. (2004). Organizational climate and company productivity: The role of employee affect and employee level. Journal of Occupational and Organizational Psychology, 77(2), 193-216.

Piperkova Majovski, I. (2014). Factors of job dissatisfaction among employees during recession. In B. Angelova, D. Jurlina Alibegović, \& S. Redžepagić (Eds.), Contemporary trends and prospects of economic recovery (pp. 550-565). Nice: CEMAFI International.

Reeves, A., McKee, M., Gunnell, D., Chang, S.-S., Basu, S., Barr, B., et al. (2015). Economic shocks, resilience, and male suicides in the Great Recession: Cross-national analysis of 20 EU countries. European Journal of Public Health, 25(3), 404-409.

Roelen, C. A. M., Koopmans, P. C., \& Groothoff, J. W. (2008). Which work factors determine job satisfaction? Work, 30(4), 433-439. 
Sánchez-Sánchez, N., \& Namkee, A. (2018). Is job satisfaction of high-level managers and self-employed more pro-cyclical than normal employees? International Journal of Manpower, 39(6), 800-819.

Sociaal en Cultureel Planbureau. (2014). Toelichting Arbeidsaanbodpanel 1985-2014 [Explanation Arbeidsaanbodpanel 1985-2014]. The Hague: Sociaal en Cultureel Planbureau.

Sociaal en Cultureel Planbureau (SCP). (2016). Arbeidsaanbodpanel $1985 \mathrm{t} / \mathrm{m} 2014$.

Spector, P. E. (1997). Job satisfaction: Application, assessment, causes, and consequences. Thousand Oaks, CA: SAGE Publications.

Stuckler, D., Basu, S., Suhrcke, M., Coutts, A., \& McKee, M. (2009). The public health effect of economic crises and alternative policy responses in Europe: An empirical analysis. Lancet, 374(9686), 315-323.

The Financial Crisis Inquiry Commission. (2011). The financial crisis inquiry report: Final report of the national commission on the causes of the financial and economic crisis in the United States. Washington, DC: US Government Printing Office.

Van Echtelt, P., Croezen, S., Vlasblom, J. D., De Voogd-Hamelink, M., \& Mattijssen, L. (2016). Aanbod van Arbeid 2016: Werken, zorgen en leren op een flexibele arbeidsmarkt [Supply of labor 2016: Working, caring, and learning on a flexible labor market]. The Hague: Sociaal en Cultureel Planbureau.

Vlasblom, J. D., Van Echtelt, P., \& De Voogd-Hamelink, M. (2015). Aanbod van Arbeid 2014: Arbeidsdeelname, flexibilisering en duurzame inzetbaarheid [Supply of labor 2014: Labor participation, flexibilization, and sustainable employability]. The Hague: Sociaal en Cultureel Planbureau.

Whitman, D. S., Van Rooy, D. L., \& Viswesvaran, C. (2010). Satisfaction, citizenship behaviors, and performance in work units: A meta-analysis of collective construct relations. Personnel Psychology, 63(1), 41-81.

Wickham, H. (2014). Tidy data. Jounal of Statistical Software, 59(10), 1-23.

Wilson, S. H., \& Walker, G. M. (1993). Unemployment and health: A review. Public Health, 107(3), $153-162$.

World Health Organization. (2009). The financial crisis and global health: Report of a high-level consultation World Health Organization. Geneva: World Health Organization.

Wright, T. A., \& Bonett, D. G. (2007). Job satisfaction and psychological well-being as nonadditive predictors of workplace turnover. Journal of Management, 33(2), 141-160.

Publisher's Note Springer Nature remains neutral with regard to jurisdictional claims in published maps and institutional affiliations. 